AWEJ for Translation \& Literary Studies, Volume3, Number1. February 2019

DOI: http://dx.doi.org/10.24093/awejtls/vol3no1.3

Pp.35-52

\title{
Female Struggle and Triumph: The Cases of Antigone, Desdemona, and Erminia
}

\author{
Ibrahim Alhiyari \\ English Department, College of Arts and Sciences \\ Gulf University for Science and Technology \\ Meshref, Kuwait
}

\begin{abstract}
The history of misogyny and varied abuse of females throughout humankind's history is well known, as this essay's discussion of the iconic figures of Antigone and Desdemona attempts to selectively chronicle. The exceptional abuse they are subjected to by their supposed benefactors is counterpoised by the debuting of Behn's Erminia as a reformist, benevolent, and angelic tour-deforce at the commencement of the Restoration. The historic example of Erminia, the representative of a new generation of young, liberated women is in remarkable contrast to her immediate historical analog, Desdemona, who is demeaned and treated as a beast as she "turn[s]" and grovels before her proprietor. Erminia's horrifically abused precedent helps to put into perspective the Restoration's perceptible progress in women's rights inasmuch as it highlights the egregious miscarriage of justice prior to the age through history. The uniqueness of the trio is clearly observed as Erminia boldly takes to the stage to reform, enchant, and restrain the savage, beastly instinct of man, and successfully rehabilitates Alcippus, while the rhetorical supremacy and ethical purpose of Antigone and Desdemona overshadow their catalyst companions, Ismene, the chorus, and Emilia. Through juxtaposing these female icons who belong to widely diverse epochs, this essay aims at analyzing their interactive dialectic in addition to scrutinizing the shifting dynamics of their socio-political and cultural milieu in order to arrive at a better understanding of the historic transition the female quest for recognition has undergone.
\end{abstract}

Keywords: Antigone, Desdemona, Erminia, gender, misogyny, patriarchal, restoration

Cites as: Alhiyari, I. (2019). Female Struggle and Triumph: The Cases of Antigone, Desdemona, and Erminia. Arab World English Journal for Translation \& Literary Studies, 3 (1) 35-52. DOI: http://dx.doi.org/10.24093/awejtls/vol3no1.3 